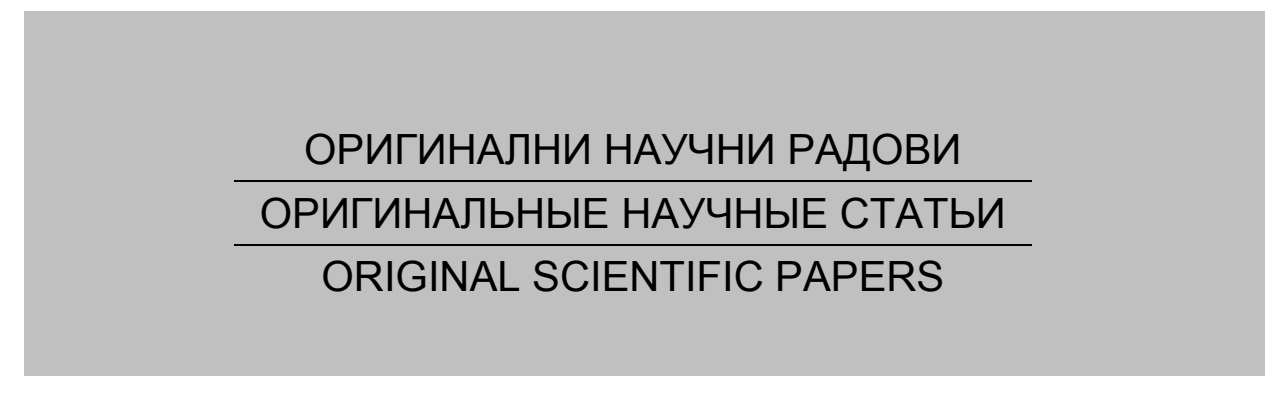

\title{
LEACHING OF RARE EARTH ELEMENTS FROM BASTNASITE ORE (SECOND PART)
}

Srećko R. Stopića ${ }^{a}$ Bernd G. Friedrich ${ }^{b}$

RWTH Aachen University, IME Process Metallurgy and Metal

Recycling, Aachen, Federal Republic of Germany

a e-mail: sstopic@ime-aachen.de,

ORCID iD: 『http://orcid.org/0000-0002-1752-5378

b e-mail: bfriedrich@ime-aachen.de,

ORCID iD: (Dhttp://orcid.org/0000-0002-2934-2034

DOI: 10.5937/vojtehg67-20103; https://doi.org/10.5937/vojtehg67-20103

FIELD: Chemical Technology

ARTICLE TYPE: Original Scientific Paper

ARTICLE LANGUAGE: English

Summary:

Dissolution of rare earth elements from bastnasite ore was studied using different leaching agents such as sulfuric acid, hydrochloric acid, acetic acid, citric acid and sodium hydroxide at $70^{\circ} \mathrm{C}$, with $1 \mathrm{~mol} / \mathrm{L}$, solid/liquid ratio of 0.05 between 30 and $180 \mathrm{~min}$. The one-step direct leaching strategy was applied under atmospheric pressure aiming at selective leaching of rare earth elements from a matrix of iron oxides in which the rare earth elements - carbonates \& flourides - are embedded.

Key words: rare earth elements, hydrometallurgy, bastnasite, acids.

\section{Introduction}

Rare earth elements are a group of metallic elements of the periodic table, often overlooked, but very significant in today's industrial landscape and modern lifestyle. Like other metals, rare earths are silvery-gray, malleable, ductile, and they conduct electricity.

ACKNOWLEDGMENTS: The research leading to these results has received funding from the European Community's Seventh Framework Programme (Call identifier FP7-NMP2012-LARGE-6) under grant agreement $n^{\circ} 309373$. This publication reflects only the author's view, exempting the Community from any liability. Project website: www.eurare.eu. We would like to thank FEN Minerals, Norway, for sending their Rodberg sample and for their discussion in our experimental work. Especially, I would like to thank Maria Jose Gallego for the participation in the experimental work and the discussion of the results. 
They appear in nature in the form of oxides and other compounds, but with one particularity - the chemical similarity between all of them is so astounding that they all occur together in their bearing minerals, substituting one another at the molecular level (Gupta \& Krishnamurthy, 2005), (Castor \& Hedrick, 2006, pp.769-772).

Development of new advanced materials based on oxidic powders is of high importance for different applications in modern life (Kuburović et al, 2018, pp.771-835).

Bastnasite $(\mathrm{La}, \mathrm{Ce}) \mathrm{CO}_{3} \mathrm{~F}$ is a fluororcarbonate of the cerium group found in ore deposits, metamorphic zones and pegmatites. In average, it contains $70 \%$ rare earth oxides, most of them belonging to the light fraction and in particular lanthanum, cerium and neodymium (Stopić \& Friedrich, pp.757-770). A sulfuric acid leaching process was studied for the processing of roasted ore of Dechang bastnasite in Sichuan, China, in order to obtain rare earth elements (Feng et al, 2013, pp.849-854). With a particle size of $0.074-0.100 \mathrm{~mm}, 1.5 \mathrm{~mol} / \mathrm{L}$ sulfuric acid concentration, a liquid to solid mass ratio of 8 and a stirring speed of $500 \mathrm{rpm}$, the reaction rate of the leaching process can be controlled by diffusion through the product/ash layer, as described by the shrinkingcore model, and the calculated activation energy of 9.97, which is typical for a diffusion controlled process.

The main equations ruling dissolution in sulfuric acid are described as:

$$
\begin{aligned}
& 2 \mathrm{REFCO}_{3}+3 \mathrm{H}_{2} \mathrm{SO}_{4} \rightarrow \mathrm{RE}_{2}\left(\mathrm{SO}_{4}\right)_{3}+2 \mathrm{HF}+2 \mathrm{H}_{2} \mathrm{CO}_{3} \\
& \mathrm{CaCO}_{3}+\mathrm{H}_{2} \mathrm{SO}_{4} \rightarrow \mathrm{CaSO}_{4}+\mathrm{H}_{2} \mathrm{CO}_{3} \\
& \mathrm{Fe}_{2} \mathrm{O}_{3}+3 \mathrm{H}_{2} \mathrm{SO}_{4} \rightarrow \mathrm{Fe}_{2}\left(\mathrm{SO}_{4}\right)_{3}+3 \mathrm{H}_{2} \mathrm{O} \\
& \mathrm{MnO}+\mathrm{H}_{2} \mathrm{SO}_{4} \rightarrow \mathrm{MnSO}_{4}+\mathrm{H}_{2} \mathrm{O}
\end{aligned}
$$

The aim of this work is to compare the leaching efficiency of different leaching agents such as sulfuric acid, hydrochloric acid, acetic acid, citric acid and sodium hydroxide at $70^{\circ} \mathrm{C}$, using $1 \mathrm{~mol} / \mathrm{L}$, solid/liquid ratio of 0.05 between 30 and 180 min in order to recover rare earth elements. 


\section{Experimental work, material, parameters and procedure}

The Rodberg ore sample used in these trials was analyzed and the results are given in Table 1 and Figure 1. The amount of iron of about 10.63 was smaller in comparison to the one of $73.1 \%$ mentioned in our previous work (Stopic \& Friedrich, 2018, 757-770), where the RE-content seems to be fairly lower than in the representative Rodberg samples.

Table 1 - Chemical composition of the "Rodberg bastnasite ore" sample

Таблица 1 - Химический состав образца «Родбергский бастнезит - минерал, содержащий, фрторкарбонат»

Табела 1 - Хемијски састав узорка „Родберг руда које садрже фолуорокарбонатни минерал"

\begin{tabular}{|l||l|l|l|l||l|l|l|l|l||l|}
\hline Element & $\mathrm{Fe}$ & $\mathrm{Ca}$ & $\mathrm{Mg}$ & $\mathrm{Mn}$ & $\mathrm{La}$ & $\mathrm{Ce}$ & $\mathrm{Nd}$ & $\mathrm{Sm}$ & $\mathrm{Y}$ & $\mathrm{Th}$ \\
\hline$(\%)$ & 10.63 & 15.15 & 4.28 & 1.50 & 0.22 & 0.43 & 0.18 & 0.025 & 0.0124 & 0.057 \\
\hline
\end{tabular}

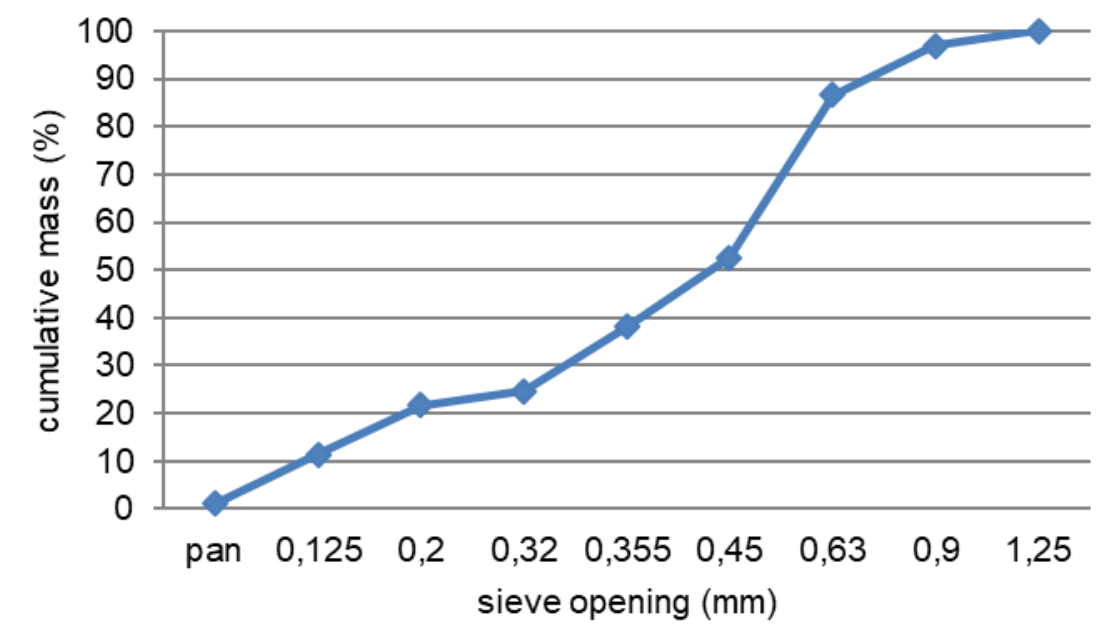

Figure 1 - Particle size distribution of the Rodberg ore

Pис. 1 - Распределение величины частиц «Родбергской руды» Слика 1 - Расподела величине честица руде „Родбере“ 
Table 2 - Leaching trial design with sulfuric-, hydrochloric-, acetic and citric acid and sodium hydroxide

Таблица 2 - Разработка пробного выщелачивания с использованием серной, соляной, уксусной и лимонной кислот и гидроксида натрия

Табела 2 - План експеримената лужења сумпорном, хлороводоничном, сирћетном и лимунском киселином и натријум-хидроксидом

\begin{tabular}{|l|l|}
\hline Parameter & set value \\
\hline \hline Concentration $(\mathrm{mol} / \mathrm{L})$ & $1(0.5)$ \\
\hline Temperature $\left({ }^{\circ} \mathrm{C}\right)$ & 70 \\
\hline Solid-liquid ratio $(\mathrm{g} / \mathrm{L})$ & 50 \\
\hline Time $(\mathrm{min})$ & $30,60,120,180$ \\
\hline Stirring rate $(\mathrm{rpm})$ & 300 \\
\hline
\end{tabular}

A sample of the Rodberg ore was submitted to a series of preliminary trials where the leaching parameters were kept constant in all experiments and only the leaching agent was changed. The aim of these experiments was to obtain information about the general behavior of the Rodberg ore under acid and alkali attacks, and to choose a route for further experimentation. The desired leaching agent should not dissolve much of the iron oxide matrix and should attack the carbonate rare earth bearing minerals instead. However, this means that the non-rare earth bearing carbonates present in the ore will almost inevitably dissolve as well.

As well as the standard mineral acids, sulfuric and hydrochloric acid, and the base sodium hydroxide, two organic acids, acetic and anhydrous citric acid, were used as leaching reagents. The purpose of the organic acid trials was to investigate whether or not calcium carbonate and ankerite (a carbonate of iron, magnesium and manganese), which add up to $17 \%$ of the ore, could be selectively leached from the ore in the first leaching step. This would allow for the removal of most of the ore's impurities. The second step involving strong mineral acid leaching could then be performed to recover the rare earth elements in a solution of higher purity.

The experiments were carried out in a laboratory fume cabinet, as shown in Figure 2. A $2 \mathrm{~L}$ beaker was placed on top of a heating induction plate and filled with one liter of the previously prepared diluted acid or reagent. A temperature measuring device was connected to the induction plate for adequate temperature control. The temperature was set at $70^{\circ} \mathrm{C}$. The stirring equipment was fixed to a clamp above the beaker and 
connected at a speed of 300rpm. Rod stirrers were used instead of magnetic stirrers because of the magnetic nature of the ore.
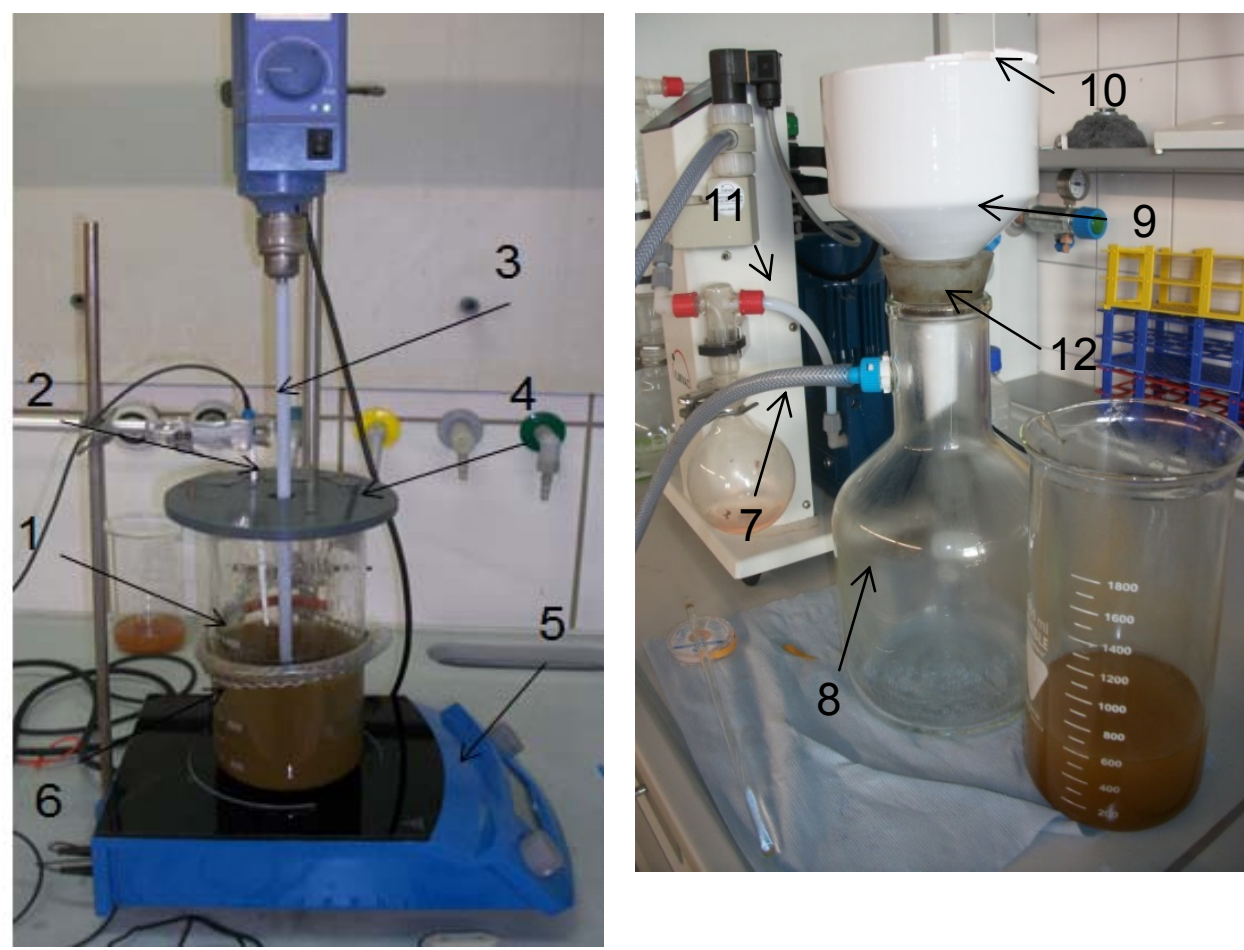

Where: 1. Beaker containing Rodberg ore + leaching agent, 2. Thermocouple, 3. Stirrer, 4. Cover, 5. Heating plate, 6. Security chain, 7. Pipe connected with a vacuum pump, 8. Glass container, 9. Ceramic filtering cone, 10. Fine filtering paper, 11. Vacuum filtering mashine, 12. Rubber adapter.

Figure 2 - Equipment for leaching and filtration

Pис. 2 - Оборудование для выщелачивания и фрильтрации

Слика 2 - Апаратура за лужење и фрилтрацију

After reaching the desired temperature, the weighed $50 \mathrm{~g}$ of the Rodberg ore were added, and the stop watch started. A cover was placed over the beaker to avoid excessive evaporation. The samples were taken from the leaching mixture by means of a syringe at several intervals: $30,60,120$ and $180 \mathrm{~min}$.

The taken samples were filtered using the previously weighed fine filter papers and the leachate was collected in the test tubes. Each sample gave about $40 \mathrm{ml}$. The used filter papers were then placed over a 
vacuum filtering machine were they were neutralized with distilled water before being introduced into a drying cabin at $105^{\circ} \mathrm{C}$ for three hours.

After the $3 \mathrm{~h}$ sample was taken, the stirrer and heating plate were disconnected and the beaker content was filtered using the above mentioned filtering machine. The filtrate was collected in a bottle and the neutralizing of the solid residue and the filter was carried out before drying in the same conditions as for the rest of the samples. After the drying time had elapsed, the solid residue was weighed and the results were noted down.

\section{Results and discussion}

The summarized results are presented in Tables 3 and 4 and Figures 3 to 6 .

Table 3 - Amount of the solid residue after leaching Таблица 3 - Количество твердого остатка после выщелачивания Табела 3 - Износ чврстог остатка након лужења

\begin{tabular}{|l|l|l|l|}
\hline $\begin{array}{l}\text { Trial } \\
\text { No }\end{array}$ & leaching agent & net mass of solid residue $(\mathrm{g})$ & mass dissolved $(\%)$ \\
\hline \hline 1 & sulphuric acid & 33.798 & 32.404 \\
\hline 2 & hydrocholric acid & 9.475 & 81.050 \\
\hline 3 & acetic acid & 29.257 & 41.486 \\
\hline 4 & anhydrous citric acid & 12.898 & 74.205 \\
\hline 5 & sodium hydroxide & 49.635 & 0.730 \\
\hline
\end{tabular}




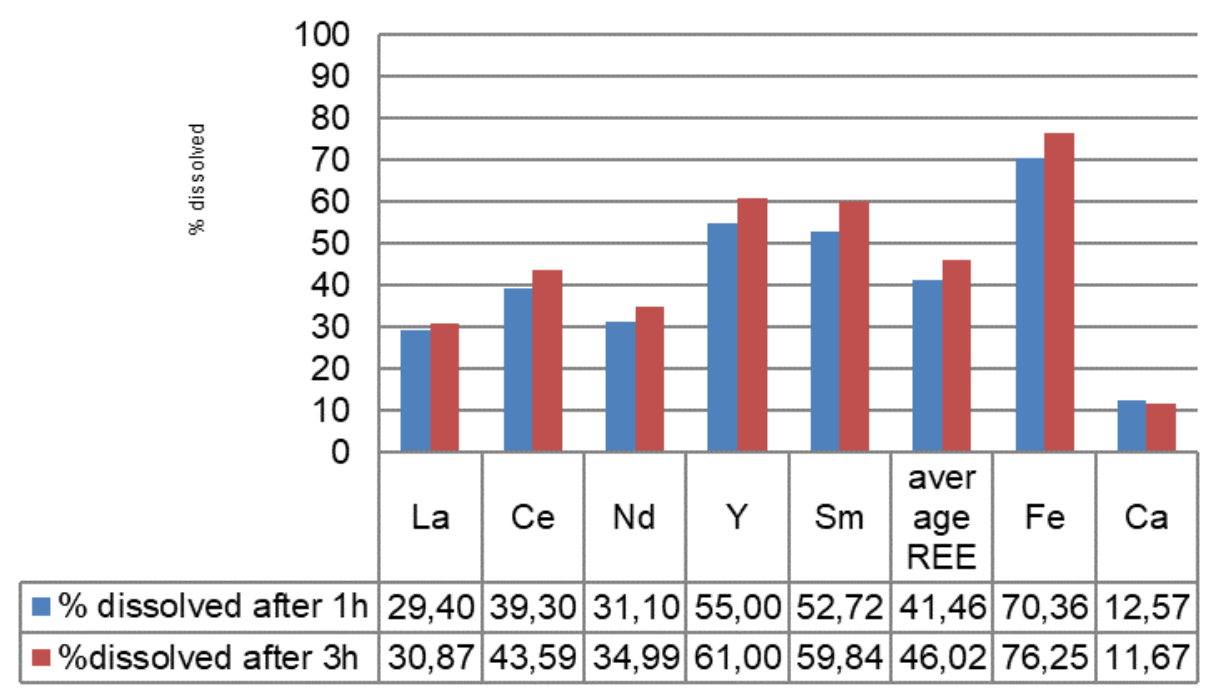

Figure 3 - Trial No1: Dissolution of rare earths and impurities during leaching with sulphuric acid

Pис. 3 - Эксперимент №1: Растворение редкоземельных элементов и примесей при выщелачивании серной кислотой

Слика 3 - Експеримент бр. 1: Растварање елемената ретких земаља и нечистоћа за време лужења сумпорном киселином

After a few hours from the leaching operation with sulfuric acid, a fine, white precipitate appeared at the bottom of test tubes and the bottle. The samples where re-filtered and the white precipitate was sent for analysis. The results are shown in Table 4.

Table 4 - Chemical composition of the precipitate produced in $\mathrm{H}_{2} \mathrm{SO}_{4}$ leaching

Таблица 4 - Химический состав осадка, образующегося при выщелачивании $\mathrm{H}_{2} \mathrm{SO}_{4}$

Табела 4 - Хемијски састав преципитата добијеног растварањем сумпорном киселином

\begin{tabular}{|l||l|l|l|l|l|l|l|l|l|l|}
\hline Element & $\mathrm{Fe}(\mathrm{ppm})$ & $\begin{array}{l}\mathrm{Ca} \\
(\%)\end{array}$ & $\begin{array}{l}\mathrm{Ce} \\
(\mathrm{ppm})\end{array}$ & $\begin{array}{l}\mathrm{La} \\
(\mathrm{ppm})\end{array}$ & $\begin{array}{l}\mathrm{Nd} \\
(\mathrm{ppm})\end{array}$ & $\begin{array}{l}\mathrm{Pr} \\
(\mathrm{ppm})\end{array}$ & $\begin{array}{l}\mathrm{Sm} \\
(\mathrm{ppm})\end{array}$ & $\begin{array}{l}\mathrm{Gd} \\
(\mathrm{ppm})\end{array}$ & $\begin{array}{l}\mathrm{Tb} \\
(\mathrm{ppm})\end{array}$ & $\begin{array}{l}\mathrm{Y} \\
(\mathrm{ppm})\end{array}$ \\
\hline Amount & $\begin{array}{l}11 /<1 \\
(\text { inhomogeneous })\end{array}$ & 29,7 & 600 & 302 & 146 & $<1$ & $<1$ & $<1$ & $<1$ & $<1$ \\
\hline
\end{tabular}

As shown in Fig. 4, leaching with hydrochloric acid had higher leaching efficiency in comparison to that with sulfuric acid. 


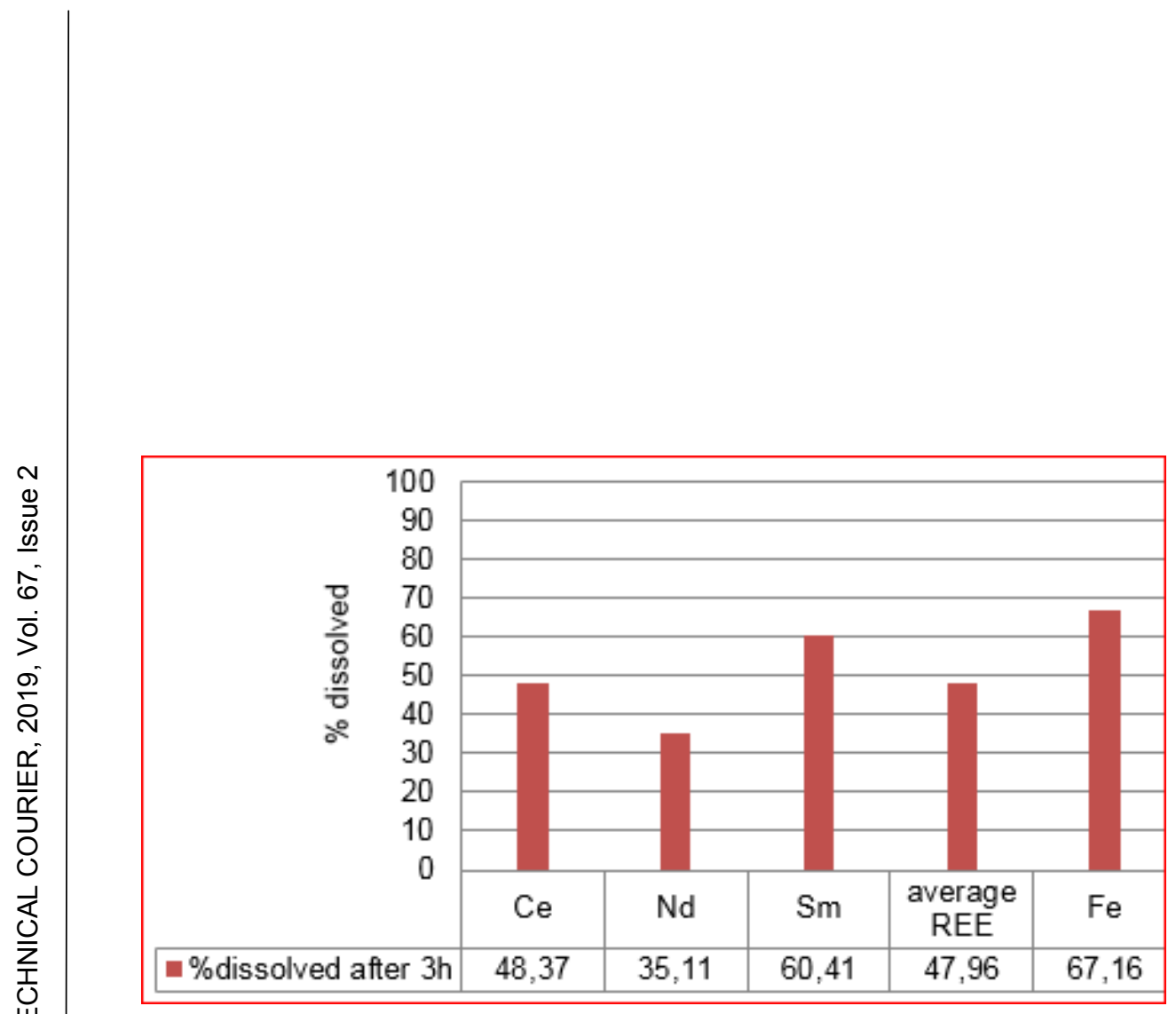

Figure 4 - Trial No 2: Dissolution of rare earths and impurities during leaching with hydrochloric acid

Puс. 4 - Эксперимент № 2: Растворение редкоземельных элементов и примесей при выщелачивании соляной кислотой

Слика 4 - Експеримент бр. 2: Растварање елемената ретких земаља и нечистоћа за време лужења хлороводоничном киселином

The chemical reactions ruling carbonate and fluoride dissolution are described as:

$$
\begin{aligned}
& \mathrm{RE}_{2}\left(\mathrm{CO}_{3}\right)_{3}+6 \mathrm{HCl} \rightarrow 2 \mathrm{RECl}_{3}+3 \mathrm{H}_{2} \mathrm{O}+3 \mathrm{CO}_{2} \\
& \mathrm{REF}_{3}+\mathrm{HCl} \rightarrow \mathrm{RECl}_{3}+3 \mathrm{HF}
\end{aligned}
$$

Leaching with organic acids was performed using acetic and citric acid, as shown in Figs. 5 and 6.

The results show that the extraction of rare earth elements was higher with mineral acids than with organic acids. Sulfuric acid dissolved $46 \%$ REE after 3 hours while hydrochloric acid dissolved $48 \%$. However, the dissolution of large quantities of iron took place in parallel, $76 \%$ in the case of sulfuric acid and $67 \%$ in the case of hydrochloric acid. Hydrochloric acid also dissolved the totality of calcium present in the ore (an error in the chemical analysis or inhomogeneity of the ore gives a percentage superior to 100). Indeed, the rare earth acid carbonate minerals seem to be more resistant to acid attack than the other gangue carbonate minerals. In the sulfuric acid leachate, the dissolution values of 
calcium are much lower due to the removal of the white precipitate, identified as calcium sulfate or gypsum $\left(\mathrm{CaSO}_{4}\right)$. The precipitate also contains small quantities of rare earth elements that have been absorbed in its crystals, namely $13.9 \%$ of cerium, $13.7 \%$ of lanthanum and $8.1 \%$ of neodymium.

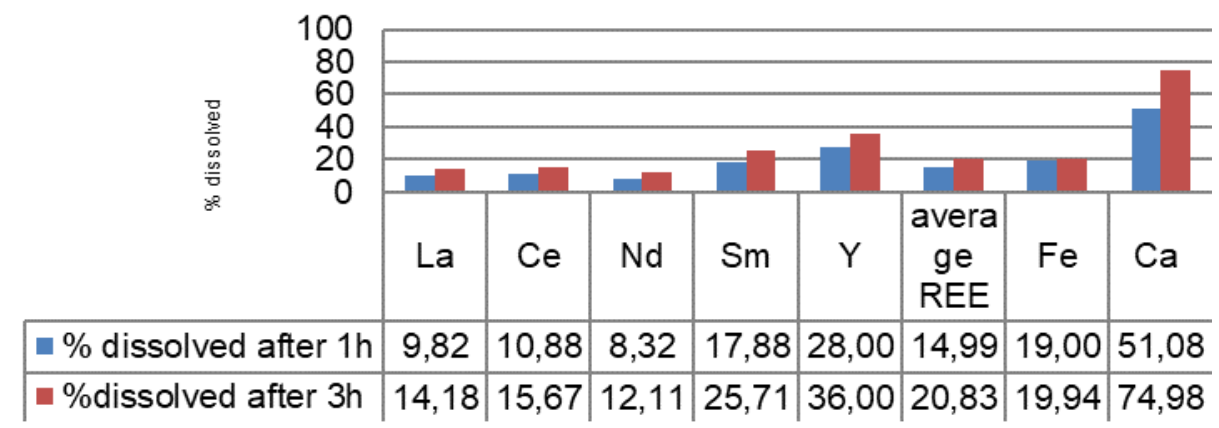

Figure 5 - Trial No 3: Dissolution of rare earths and impurities during leaching with acetic acid

Puc. 5 - Эксперимент № 3: Растворение редкоземельных элементов и примесей при выщелачивании уксусной кислотой

Слика 5 - Експеримент бр. 3: Растварање елемената ретких земаља и нечистоћа за време лужења сирћетном киселином

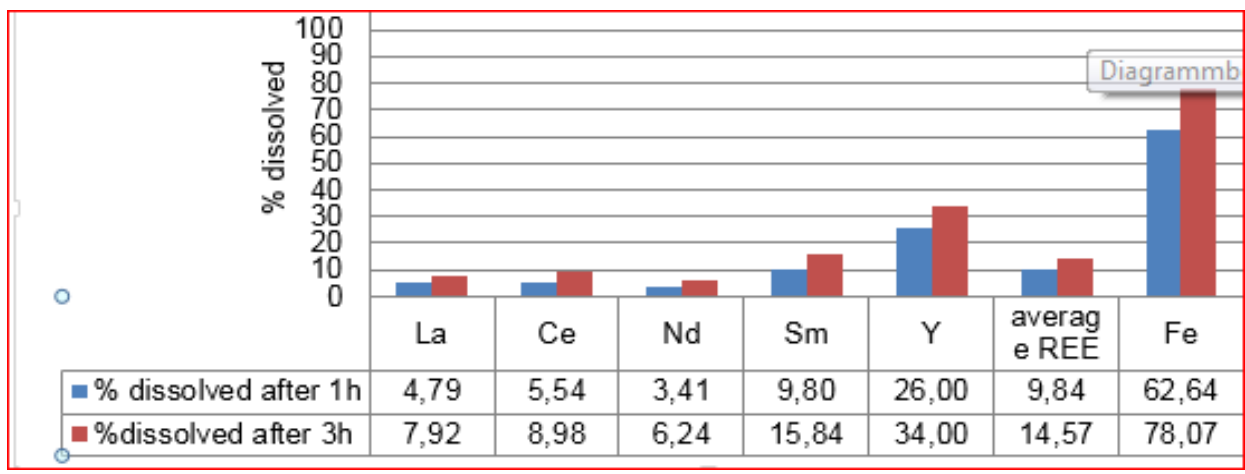

Figure 6- Trial No 4: Dissolution of rare earths and impurities during leaching with citric acid

Pис. 6 - Эксперимент № 4: Растворение редкоземельных элементов и примесей при выщелачивании лимонной кислотой

Слика 6 - Експеримент бр. 4: Растварање елемената ретких земаља и нечистоћа за време лужења лимунском киселином 
The amount of solid residue left in sulfuric acid leaching is also inferior to that of hydrochloric acid (32\% versus $81 \%$ ), although different minerals, including iron oxide, are dissolved to a similar degree. There is a possibility that a part of gypsum is precipitating too during the leaching operation with sulfuric acid, and is collected together with the solid residue counted as undissolved material.

The organic acids failed to remove the carbonate gangue minerals without dissolving the rare earth carbonate minerals. Acetic acid leached an average of $21 \%$ REE together with $20 \%$ of iron and $75 \%$ of calcium after 3 hours. Citric acid left most rare earths untouched, but dissolved a great quantity of the gangue minerals containing iron and calcium. The likeliness of a selective leaching of gangue carbonates with organic acids was overall not encouraging.

As to the base $\mathrm{NaOH}$, the total mass of ore dissolved, lower than $1 \%$, already pointed toward little rare earth recovery.Fe dissolved in $0.03 \%$ and $0.02 \%$ after 1 and 3 hours, respectively. Calcium dissolved in $0.28 \%$ and $0.13 \%$. All rare earths dissolved to give less than $1 \mathrm{mg} / \mathrm{l}$ in the solution.

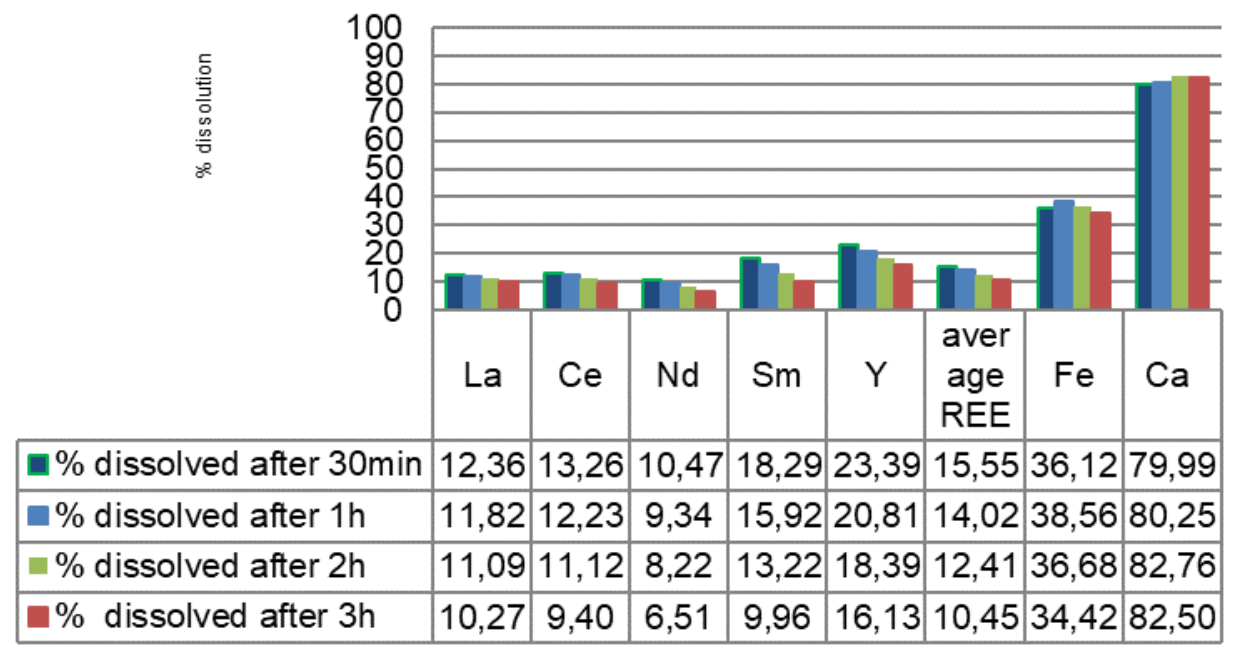

Figure 7 - Leaching in hydrochloric acid $(0.5 \mathrm{~mol} / \mathrm{L})$ - Dissolution of rare earths and impurities

Puc. 7 - Выщелачивание в соляной кислоте (0,5 моль/л). Растворение редкоземельных элементов и примесей

Слика 7 - Лужење хлороводоничном киселином (0,5 mol/L)- растварање елемената ретких земаља и нечистоћа 
In an additional leaching experiment, a possibility of selective leaching was attempted with a lower concentration of hydrochloric acid of $0.5 \mathrm{~mol} / \mathrm{L}$, leaving the rest of the parameters as previously determined. The results are shown in Figure 7.

A peculiarity of this hydrochloric acid trial is that all rare earths give larger values of dissolution after 30 minutes of leaching and the lapse of time reduces their quantity in the leachate. This does not happen with iron and calcium, which reach maximum dissolution levels after 1 and 2 hours, respectively. After 30 minutes, an important quantity of calcium, $80 \%$, was leached, versus $16 \%$ REE, $10 \%$ in the case of neodymium. The amount of iron present in the leachate was $36 \%$.

When comparing the trial $\mathrm{No} 1$ done with $1 \mathrm{M} \mathrm{HCl}$ and this extra trial where the concentration has been halved to $0.5 \mathrm{M}$, it can be concluded that the dissolution of rare earths has decreased drastically in $78.21 \%$. Calcium remained with high dissolution rates, decreasing only in $17.50 \%$ in respect to the $1 \mathrm{M}$ trial, while iron was $48.75 \%$ less dissolved. This means that reducing the acid concentration was more selective toward dissolving the gangue calcium based minerals and not the rare earth bearing minerals. Reducing the concentration further, and varying other parameters, for instance leaching at lower temperatures, with higher solid to liquid ratios and longer times, could give more accurate results, and the possibility of a two-step leaching process.
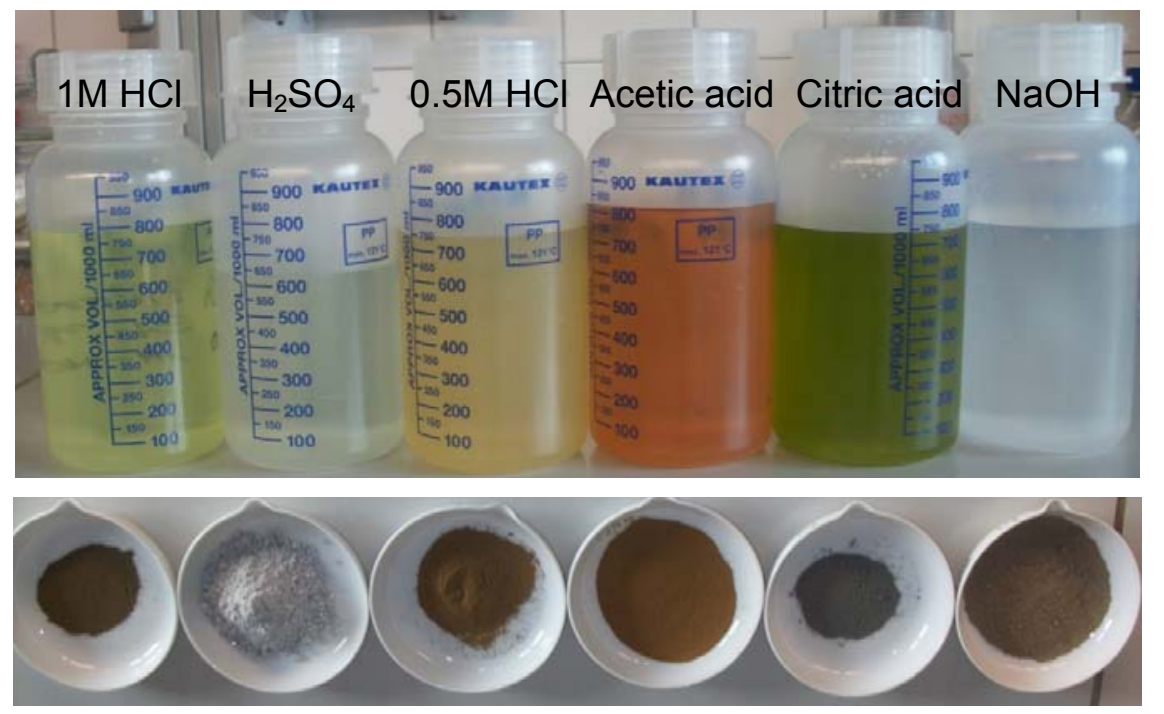

Figure 8 - Leachates and their corresponding solid residues

Pис. 8 - Полученные растворы и соответствующие твердые остатки Слика 8 - Добијени раствори и њима одговарајући чврсти остаци 


\section{Conclusion}

The dissolution of rare earth elements from bastnasite ore was performed using different leaching agents such as sulfuric acid, hydrochloric acid, acetic acid, citric acid and sodium hydroxide at $70^{\circ} \mathrm{C}$, using $1 \mathrm{~mol} / \mathrm{L}$, solid/liquid ratio of 0.05 with duration between 30 and 180 min. The maximal leaching efficiency was about $48 \%$ under the above mentioned conditions using hydrochloric acid and sulfuric acid in contrast to $20 \%$ obtained using acetic and citric acid. A decrease in the concentration of hydrochloric acid from 1.0 to $0.5 \mathrm{~mol} / \mathrm{L}$ leads to a decrease in the leaching efficiency to $11 \%$.

In order to increase the leaching efficiency of rare earth elements, an additional study of the increased concentration and higher pressure and temperature in an autoclave will be performed. The minimal leaching efficiency was obtained using sodium hydroxide for dissolution of rare earth elements from a bastnasite ore. Higher dissolution of iron and calcium under the above mentioned conditions is a serious problem for the leaching process selectivity.

\section{References}

Castor, S.B., \& Hedrick, J.B. 2006. Rare Earth Elements. In: Kogel, J.E., Trivedi, N.C., Barker, J.M., \& Krukowski, S.T. Industrial Minerals and Rocks: Commodities, Markets, and Uses, 7th edition. SME. P.1568.

Feng, X., Long, Z., Cui, D., Wang, L., Huang, X., \& Zhang, G. 2013. Kinetics of rare earth leaching from roasted ore of bastnaesite with sulfuric acid. Transactions of Nonferrous Metals Society of China, 23(3), pp.849-854. Available at: https://doi.org/10.1016/s1003-6326(13)62538-8.

Gupta, C.K., \& Krishnamurthy, N. 2005. Extractive Metallurgy of Rare Earths. Boca Raton, FI: CRC Press. chapter 1.2; ISBN 0415333407 9780415333405.

Kuburović, N., Golubović, A., \& Babinčev, Lj. 2018. Development of new smart metal nanomaterials based on titanium-dioxide for photocatalytic and antimicrobial activities. Vojnotehnički glasnik/Military Technical Courier, 66(4), pp.771-835. Available at: https://doi.org/10.5937/vojtehg66-17261.

Stopić, S., \& Friedrich, B, 2018. Leaching of rare earth elements with sulfuric acid from bastnasite ores. Vojnotehnički glasnik/Military Technical Courier, 66(4), pp.757-770. Available at: https://doi.org/10.5937/vojtehg6617177. 
ВЫЩЕЛАЧИВАНИЕ РЕДКОЗЕМЕЛЬНЫХ ЭЛЕМЕНТОВ ИЗ ПОРОД, СОДЕРЖАЩИХ ФТОРКАРБОНАТЫ - ВТОРАЯ ЧАСТЬ

Сречко Р. Стопич, Бернд Г. Фридрих

Технический университет города Ахен,

Институт металлургических процессов и рециклирования металлов,

Ахен, Федеративная Республика Германия

РУБРИКИ: 61.13.21 Химические процессы

ВИД СТАТЬИ: оригинальная научная статья

ЯЗЫК СТАТЬИ: английский

Резюме:

При исследовании процесса растворения редкоземельных рудных пород, содержащих фрторкарбонат применялись различные виды выщелачивания: серной кислотой, соляной кислотой, уксусной кислотой, лимонной кислотой и гидроксидом натрия, при температуре $70^{\circ} \mathrm{C}$, концентрация: 1 моль / л, соотношение твердость/жидкость: 0,05, в промежутке времени от 30 до 180 минут. Одностадийное выщелачивание проводилось с целью селективного выщелачивания редкоземельных элементов, в виде фторидов и хлоридов, находящихся в матрище оксида железа.

Ключевые слова: редкоземельные элементы, гидрометаллургия, фоторкарбонат, серная кислота.

РАСТВАРАЊЕ ЕЛЕМЕНАТА РЕТКИХ ЗЕМАЉА ИЗ РУДА КОЈЕ САДРЖЕ ФЛУОРОКАРБОНАТНИ МИНЕРАЛ (ДРУГИ ДЕО)

Срећко Р. Стопић, Бернд Г. Фридрих

Технички универзитет у Ахену, Институт за процесну металургију и рециклирање метала, Ахен, Савезна Република Немачка

ОБЛАСТ: хемијске технологије

ВРСТАЧЛАНКА: оригинални научни рад

ЈЕЗИК ЧЛАНКА: енглески

Сажетак:

Растварање елемената ретких земаља из руда које садрже фрлуорокарбонатни минерал проучавано је коришћењем разних реагенаса за лужење, као што су сумпорна, хлороводонична, сирћетна $и$ лимунска киселина $и$ натријумхидроксид, концентрације $1 \mathrm{~mol} / \mathrm{L}$, на $70^{\circ} \mathrm{C}$ у времену од 30 до 120 минута и односом чврсто/течно од 0,05. Директно лужење у једном кораку извођено је са циљем селективног лужења елемената ретких земаља у облику фллуорида и хлорида, који су заробљени у матрици гвожђе оксида.

Кључне речи: елементи ретких земаља, хидрометалургија, фолуорокарбонатни минерал, сумпорна киселина. 
Paper received on / Дата получения работы / Датум пријема чланка: 05.01.2019. Manuscript corrections submitted on / Дата получения исправленной версии работы / Датум достављања исправки рукописа: 24.02.2019.

Paper accepted for publishingon / Дата окончательного согласования работы / Датум коначног прихватања чланка за објављивање: 26.02.2019.

() 2019 The Authors. Published by Vojnotehnički glasnik / Military Technical Courier

(www.vtg.mod.gov.rs, втг.мо.упр.срб). This article is an open access article distributed under the terms and conditions of the Creative Commons Attribution license (http://creativecommons.org/licenses/by/3.0/rs/).

(c) 2019 Авторы. Опубликовано в «Военно-технический вестник / Vojnotehničkiglasnik / MilitaryTechnical Courier» (www.vtg.mod.gov.rs, втг.мо.упр.срб).Данная статья в открытом доступе и распространяется в соответствии с лицензией «CreativeCommons» (http://creativecommons.org/licenses/by/3.0/rs/).

() 2019 Аутори. Објавио Војнотехнички гласник / Vojnotehničkiglasnik / MilitaryTechnicalCourier (www.vtg.mod.gov.rs, втг.мо.упр.срб). Ово је чланак отвореног приступа и дистрибуира се у складу са CreativeCommonslicencom (http://creativecommons.org/licenses/by/3.0/rs/). 